Original Research Paper

\title{
City Growth: Issues and Challenges of Urban Sustainability in Republic of Benin
}

\author{
Aboubakari Moussa \\ Send Message Economics, Marmara University, Turkey
}

Article history

Received: 6-06-2017

Revised: 2-08-2017

Accepted: 30-10-2017

Email: aboubakarimoussa@gmail.com

\begin{abstract}
The reason behind the sustainable urban development in many developing countries, including Benin are diverse such as socioeconomic, environment and cultural challenge. The aim of this paper therefore is to examine the growth of cities in Benin, issues and challenges of urbanization in order to have a sustainable urban development. The mains area addressed in the paper are: issues related to local institutions and local governance, the challenge of urban growth sustainability in Benin and then the need to reinvent a new model of governance for a sustainable urbanization and for the financial sufficient of municipalities in Benin. Further, to reach my goal I will answer to the following questions: which policies for the effective and sustainable urban development? How cities/municipalities can accumulate wealth from local resources in order to be more or less dependent from the central state or others external source rather than their own?
\end{abstract}

Keywords: Cities Growth, Sustainable Development, Local Government, Decentralization, Republic of Benin

\section{Introduction}

Urbanization is increasing and cities have come to have a dominant role in global development and its impacts on environment and socio-economic challenges (UN-Habitat, 2010). Urban population is growing steadily over time since the world population is increasing in a high rate.

Understanding the formation of cities is crucial to face the challenge that new cities may encounter. Cities growth and formation in developing countries is very rapid, but authorities are sometime not aware of the situation. While the enormous growth of urban populations in many countries is known, the rapid increase in the number of cities is not (Henderson and Venables, 2009). Urbanization in Africa is growing very fast. According to the UN-Habitat (2010), the rate of urbanization soared from 15 percent in 1960 to 40 percent in 2010, and is projected to reach 60 percent in 2050. Moreover, in the next 45 years the UNs projected two billion person increase in the world urban population ensures this growth in cities will continues.

The growing of cities has received a little public attention over the few decades. The spatial redistribution is for a great importance in nowadays cities formation trend due to the population growth dynamic. A huge increase in urban population are foreseen in developing countries and challenged with the spatial redistribution followed with a socio-economic implications. The interest in regional nomenclature has declined. Urbanization in Africa has happened very quickly, but brought little change in the economic structure of its countries and in sub-Saharan African countries its expansion have recently accelerated (Freire and Leipziger, 2014; Hove et al., 2013). Within the context of ongoing development patterns in regional economic, local institutions may be the core interest of discourse. Good governance in local institutions will ensure a prominent urbanization as the central government is more concern about the overall development than a particular city. Participation in urban development has to be done in inclusive manner without exception of a particular group. Instead of the government, cities are getting their support from outside mostly from NonGovernmental Organization (NGOs) or international partnership between cities. The local governance will be widely discuss in the paper by taking into account the decentralization and the management of local institutions in developing country particularly in Benin.

The developed countries like USA, Canada, and Germany have a higher degree of decentralization of authorities and different levels of government (Talmaciu, 2014). A good local governance is followed by a sustainable development thus, the challenge of urban 
growth sustainability is going to be my second discussion in this paper. To enhance sustainability in growing cities, local authorities have to make critical choices about what issues to give priority. In addition, the basic challenges of urban growth that may conduct to a sustainable city management involve the expansion and management of services, the collection and allocation of sufficient incomes to create infrastructure and to operate services in an adequate fashion (Freire, 2006). The political dispute always take precedence over the development of cities in Benin. For instance a regime in power will support a particular local development without condition if the authorities of this region support the regime. In that sense, it is necessary to rethink and reinvent a new model of local governance in order to have sustainable regional development as the regime change local authorities may change as well. Although Benin adopt the decentralization since 1999, there are always an invisible hand in the local region management. The Fig. 1 show the population evolution in Benin. Till 2030 the 9 departments are expected to reach 1 million population each and 4 departments will be close to 2 million each.

The paper is organized in 7 sections. The first section concern the experience of decentralization in Republic of Benin since 1999, the second section will concerned the theoretical framework followed with local institutions and governance. In the fourth section I will discuss the challenge of urban growth sustainability, section five will be about the effective and sustainable policies. The section six will concerned the financial aspect of communes and taxes collection and then finish with the conclusion and remarks.

\section{Decentralization in Benin Since 1999}

Decentralization is "the transfer of responsibility for planning, management, and resource-raising and allocation from the central government to (a) field units of central government ministries or agencies; (b) subordinate units or levels of government; (c) semiautonomous public authorities or corporations; (d) areawide regional or functional authorities; or (e) NGOs/PVOs" (Rondinelli, 1981). Decentralization is see as the way to reduce overload and congestion in the central state management. It is often seen as a meant of increasing the ability of central government officials to get better and less suspect information about local or regional conditions, to plan local programs more responsively, and to react more quickly to unanticipated problems that inevitably arise during implementation (Maddick, 1963).

In the aftermath of the national conference of vital forces in 1990, it has been recommended to establish a nomenclature of territories in Republic of Benin. This structure of territories created 77 communes, and 12 departments. The legal and institutional framework adopted in 1999 which steward this new political and administrative system (decentralization) transfer a welldefined competences to the municipalities (Giz, 2010). Before this decentralization came effective in Benin, it takes different step as follow.

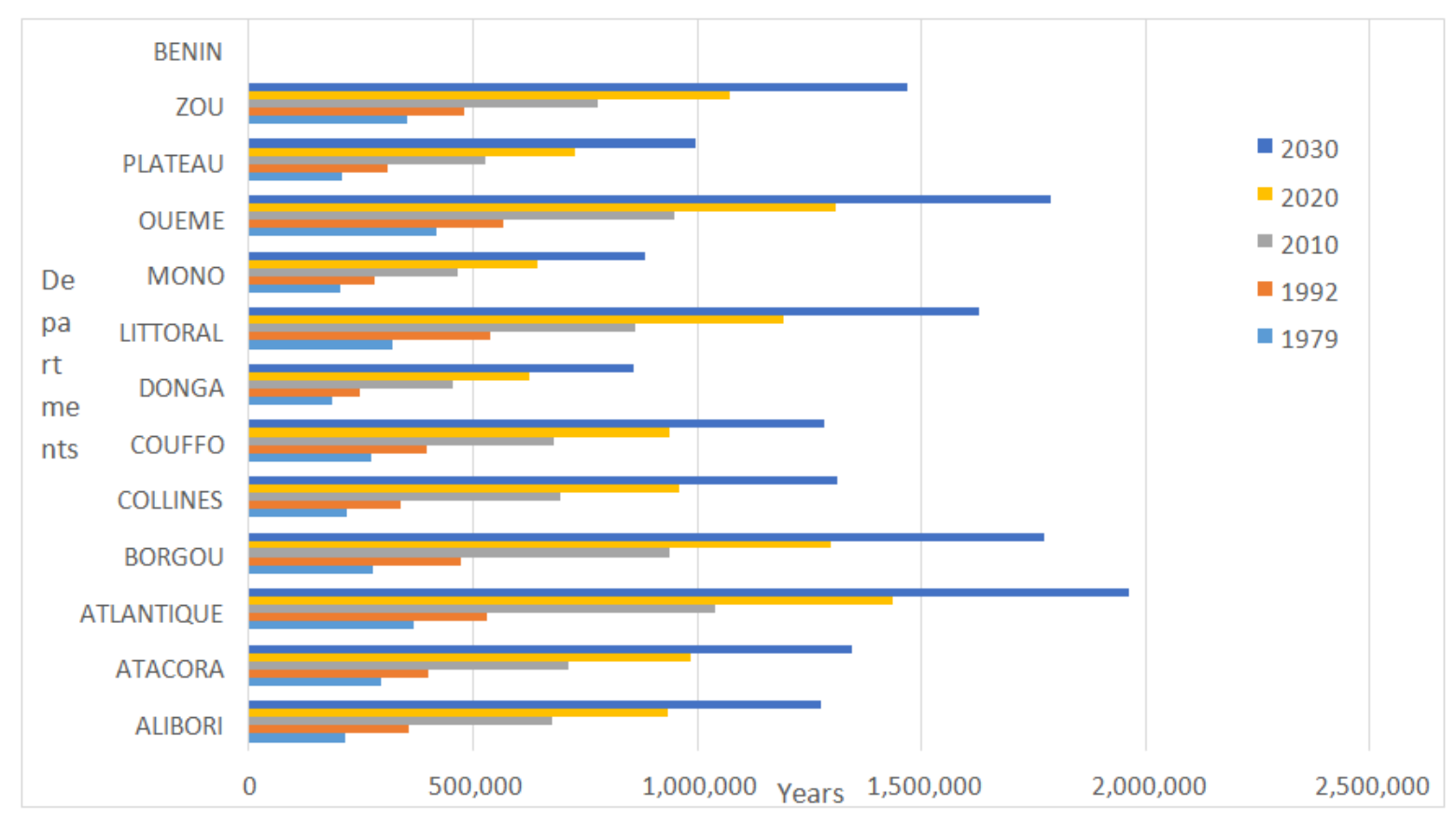

Fig. 1: Population evolution in Benin, Source: author own computation base on INSAE data 
As part of the implementation of the recommendations issued by the Conference of the Forces Vives de la Nation held from 19 to 28 February 1990, the Benin State set up a number of projects, namely:

1. The held General assessment on Territorial Administration from 7 to 10 January 1993, during which the guiding principles of the new organization of the Territorial Administration were defined

2. On 25 January 1993: the Minister in charge of territorial administration set up an interministerial monitoring committee to prepare the draft of decentralization laws

3. In July 1996: the Government adopted all five bills of decentralization

4. 23 May 1997: creation of the Decentralization Mission by the bill note No. 97-254 of 23 May 1997

5. From July 1997 to February 1998: vote of the five laws by the National Assembly

6. On 15 January 1999: the Head of State promulgates the following laws:

- Law No. 97-028 on the organization of the territorial administration of the Republic of Benin

- Law No. 97-029 on the organization of the Communes in the Republic of Benin

- Law No. 98-005 on the organization of municipalities with special status

- Law No. 98-007 on the financial arrangements of the Communes in the Republic of Benin

7. On 9 March 2000: promulgation by the Head of State of Act No. 98-006 on municipal and municipal electoral systems in the Republic of Benin

8. As from 15 October 2001: several decree implementing the decentralization laws have been adopted.

9. In December 2002 and January 2003 the first communal and municipal elections were held

10. Since March 2003 the first communal / municipal councils have been set up

11. Since March 2008, Benin has had the second term of office of local elected representatives (government of Republic of Benin, 1999) (http://www.decentralisationbenin.org/spip.php?rubrique245)

Regardless of the modest success rate of decentralization in countries where it is adopted, however, Government planners, donor institutions, and observers of the development process continue to promote it (Rondinelli et al., 1983)

\section{Theoretical Framework}

\section{Urbanization and Urban Growth}

Urbanization is not a subplot, but rather the main policy narrative for Africa (Freire et al., 2014). Mabogunje (1985) defined urbanization as a process of human agglomeration in multi-functional settlement of relatively substantial size. It is refers to a rise in proportion of a total population that is concentrated in urban settlements (Rogers, 1978). The migration of rural population to the urban area create a concentration of population in one area and bring a new urban settlement. In the history, urbanization and urban growth have occurred together there are complementary to each other. The increasing in the number of population living in urban settlement refers to urban growth. The urban growth is becoming inevitable as the world population increasing at a high rate and it is particularly relevant in the $21^{\text {st }}$ century.

The rapid urban growth meant that there have been a population concentration in urban areas and challenges faced are the lack of investment in physical structure and the human capital needed to cut the expected economic benefit of agglomeration; consequence government have been less able to manage negative externalities (Freire et al., 2014). The locus of both demographic and economic growth todays is in cities and towns (Martine, 2005). Economic activities are concentrated in urban area and there are a lot of opportunities for better jobs. People are migrating to those places for better life and this lead to an increase in the number of population creating an agglomeration and a need for urban settlement as showing in the Fig. 2, Cotonou and Parakou are the cities where the immigration rate is high Porto-Novo is also a big city but the emigration is more than immigration (Porto-Novo is the capital city and very close to Cotonou the capital economic approximately $44 \mathrm{~km}$ which influence the immigration from porto-novo to Cotonou). By 2050 the Benin urban area population is projected to increase by 60 percent and at the same time the rural population will decrease by approximately 40 percent (https://esa.un.org/unpd/wup/Country-Profiles/) as showing in the appendix 1 . Presently, more than 3 billion people are living in cities and towns and this is expected to increase by 2030 to almost 5 billion and the path of developing countries to urbanization and urban growth not only differs significantly from the patterns observed in developed countries during the past, but also varies considerably by region (Martine, 2005). Thus, urbanization is necessary for countries sustainable development process. 


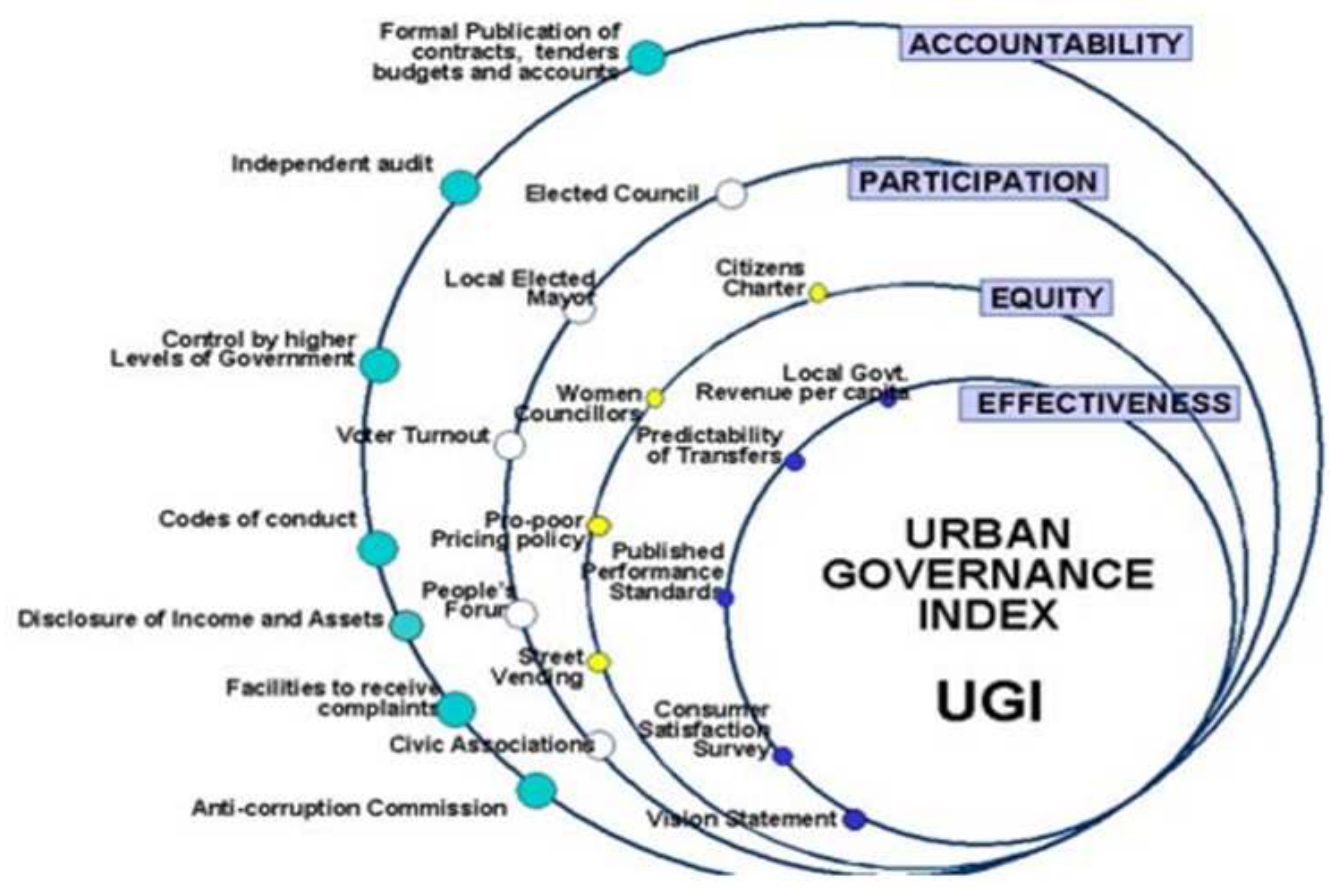

Fig. 2: Urban governance index

\section{Sustainable Development}

The Brundtland et al. (1987) defined sustainable development as 'the ability of human to ensure development that meets the needs of the present without compromising the ability of future generations to meet their own needs.' It is an ongoing process of development which embrace all aspects of economic activities. According to Grizans (2009), sustainable development is a concept of growing popularity aimed at producing long-term global well-being through the wise use and management of economic and natural resources, and through respect for people and other living things. The needs of the population have to be satisfy and the process is supposed to be inclusive. For Sarre and Smith (2013), sustainable development is comprise of two main concepts, '(i) the concept of needs, in particular the essential needs of the world's poor, to which overriding priority should be given; and (ii) the idea of limitations imposed by the state of technology and future needs' (Hove et al., 2013).

In urban area and at city level, the sustainability development is meant to embrace the sector like transportation, communication, construction and water canalization. Alberti and Susskind (1996) give four general proposition about cities sustainability, first sustainability requires invention, not just discovery; second it is an opportunity rather than a constraint; third it is a process, rather than an outcome; and finally sustainability involve a personal choice (Madu et al.,
2017). Urban sustainability should mean a long term development goal by satisfying the present needs. In a cities context, the sustainable development should comprise of the infrastructures building and the land use planning. Muller-Eie and Bjorno (2016) also make a suggestion for urban sustainability strategies on transport, resources, and built environment .

\section{Local Institutions and Governance}

Local governments are the one that are very close and have the legitimacy to effectively govern and lead the development of the city. Local governance is the better way to have inclusive local development and governance and also to face all negative externalities that may be a threat for local economic activities. 'Strong and capable local governments are the key levers to ensure inclusive and sustainable urban development, accountable and transparent city management, and a dynamic multi stakeholder engagement' (https://unhabitat.org/governance/). The issues related to local governance are the political turmoil at the local level, the externality effect and the bad management of local institutions as well as garbage and wastewater management. It is often evident that local authorities ignored the realities of local population living conditions. To assist cities in improving local governance and countries in monitoring the quality of urban governance, the UN-Habitat design the "Urban Governance index" to measure the average achievement a dimensions (effectiveness, equity, participation and accountability) of urban governance. 
Table 1: Distribution of migrants by area of residence and by department

\begin{tabular}{|c|c|c|c|c|}
\hline \multirow[b]{2}{*}{ Area } & \multicolumn{3}{|c|}{ Internal migration } & \multirow[b]{2}{*}{ Externals immigrants } \\
\hline & Immigrants & Emigrants & Balance & \\
\hline Borgou semi-rural & 24,270 & 12,003 & 12,267 & 11,058 \\
\hline Atlantique semi-rural & 33,519 & 23,463 & 10,056 & 3,087 \\
\hline Cotonou & 68,356 & 61,171 & 7,185 & 14,860 \\
\hline Zou rural & 25,208 & 18,685 & 6,523 & 6,096 \\
\hline Ouémé semi & 12,216 & 9,585 & 2,631 & 1,509 \\
\hline Parakou & 17,137 & 15,013 & 2,124 & 2,367 \\
\hline Atlantique rural & 9,176 & 8,553 & 623 & 1,885 \\
\hline Borgou rural & 2,578 & 3,744 & $-1,166$ & 977 \\
\hline Atacora rural & 2,324 & 3,922 & $-1,598$ & 1,912 \\
\hline Porto-Novo & 20,225 & 22,364 & $-2,139$ & 3,679 \\
\hline Ouémé semi rural & 132,520 & 15,931 & $-2,411$ & 3,533 \\
\hline Mono rural & 8,139 & 11,987 & $-3,848$ & 5,824 \\
\hline Mono semi rural & 12,422 & 18,152 & $-5,730$ & 5,179 \\
\hline Zou semi rural & 26,297 & 36,707 & $-10,410$ & 5,384 \\
\hline Atacora rural & 12,613 & 26,720 & $-14,107$ & 10,554 \\
\hline
\end{tabular}

Source: INSAE, RGPH2, 1992

In city level the most important negative externalities are pollution, congestion and concentration of people and assets in areas prone to pollution and naturals hazards (Freire et al., 2014). For instance in Benin, the city of Cotonou which is the biggest city and economic capital of the country experience each and every season inundation which create diseases and blockage of roads (Table 1).

Inadequate house building plan and the lack of infrastructures are the very important issues in Benin urbanization planning specially in big cities like Cotonou, Porto-Novo and Parakou. According to The Institute for Empirical Research in Political Economy (Ireep), (http://fr.africatime.com/benin/articles/gestiondes-ordures-et-eaux-usees-abomey-calavi-cotonou-etporto-novoles-resultats-) as far as Cotonou is concerned, poor management of garbage and wastewater, flooding and noise pollution are the major environmental problems of the municipality. As for the municipality of Porto-Novo, $41 \%$ of the inhabitants say that waste and wastewater management is the main problem of the city and the noise pollution comes to $16 \%$ of the population and finally the flooding for $14 \%$ (see appendix 3 ).

\footnotetext{
"Effective multilevel governance is the overarching prerequisite for urban governance, which should be characterized by well-defined spheres of government (national, regional and local) and based on appropriate decentralization policies. It calls for a balanced distribution of resources and responsibilities between the different spheres of government, enabled by legal and financial instruments that take into account the key principle of subsidiarity"(UN-Habitat, 2017).
}

\section{The Challenge of Urban Growth Sustainability in Benin}

The urban growth is necessary as the world population is increasing but at the same time we have to be aware of the challenges that this rapid growth brought. The process of urbanization which create the urban growth is already very advanced in more developed regions, where 75 percent of the population lived in urban areas (UN, 2005). This new trend of urbanization growth create a new challenges mostly for African cities. The problem of houses, lack of decent infrastructure and amenities and the most important is inability to capture the economic benefit that may be provide by the cities. According to Freire et al. (2014), much of Africa countries can be officially classified as urbanized, these settlements are urban with significant caveats and within this reality four challenges have emerged:

1. Rapid growth of populations with low levels of economic activity based on inadequate physical and human capital

2. Low density, sprawl, and informality in peri-urban fringes that exacerbate poverty in the continent

3. Weak coverage of basic infrastructure services, notably water, energy, and sanitation, which makes it difficult to improve welfare in either urban or rural environments

4. Weaknesses in administration, institutions, and overall planning capacity (Freire et al., 2014)

Benin did not escape to these challenges of development regardless of the size of the city. The most challenges face in urban growth sustainability in Benin are the poor management of local institutions sometimes due to political ambitious or a total opacity management, 
unclear policies for a reel development of urban areas. The actors implicated in the city management like policy makers, stake holders, designers, developers and urban planners are focusing more in the upgrading of slums but unfortunately nobody is concerned by the challenges of urban growth. The most affected by the deficiency of houses is the city of Cotonou which welcome population of peripheries towns because of it economic situation. Parakou also did not escape the congestion of population as it is the biggest city in the north part of Benin. The three big cities of Benin (Cotonou, Porto-Novo and Parakou) face all a mismanagement of settlement due to the increasing inflowing numbers of population. Local governments provide less public services such as transportation facilities and access to a better sanitation.

In Cotonou and others big cities of Benin, the mode of public transportation that dominate is the motorcycles. The local government of Cotonou try several times to introduce buses transportation like the case of "Benafrique" launched in August 2013 but they failed to implement it because the competition with the motorcycles was very high. But recently, the central government launched a project called "Benin-Taxi" (see appendix 4) to facilitate urban mobility. Will this new project survive the competition with the motorcycles? That is the question worth asking considering a failed similar project in the past. Urbanization is came to an inevitable process of development in most developing countries like Benin. Although it present some challenges as enumerate early, it has also its opportunities.

The large number of immigrant in cities has his economic benefit also that city authorities should considered and take advantage of it. In Cotonou, the capital economic of Benin is overflow of opportunities. People around everywhere from the four corners of the country are coming there in order to find a better job. This flow of people create new market environment. Internal migration should be encourage. Industries and business are located in or within the vicinity of big cities which provide jobs to the habitant. The employability opportunities is higher in urban areas than rural areas. As in developing countries, big cities are more attractive with a huge business opportunities.

\section{Effective and Sustainable Policies for Urban Development in Benin}

For a sustainable urban development, it is necessary to have a good policy toward city long-term development. Policies designers play a considerable role in city development process together with the local authorities. Effective policies require a certain autonomy. The central state should totally or partially liberalized the management of municipalities by transferring some powers to the local authorities. Meaning that decentralized. In the countries where decentralization is apply, local government gain some autonomies. Authority transfer from central government to local government (Municipalities) is intimately connected with economic development as policies are designed and adopted at regional level, due the acknowledgement that geography and the regional context of management matter for development strategies to be effective and sustainable. "Hence, decentralized administrations are empowered with the capacity to design and implement strategies that recognize the local cultural and socio-institutional underpinnings of regional economic interactions and behavior" (Ascani, et al., 2012).

In Benin it is necessary to have a sustainable policy in the domain of housing, water, electricity and sanitation and also slum upgrading in the big cities where population and congestion create slums. In a metropolitan areas like Cotonou which is also the biggest city of Benin it is unacceptable to have power cuts each time. According to the UN-Habitat (2010), Cities and towns have the duty to mobilize action and design policies towards improving housing conditions in slums like a means of meeting a basic human need as slum and informal settlement upgrading becomes part of a town or cities broader urban vision. This sustainable policy mean that design a short and long-term agendas. One of the biggest threat to a better and efficient policy in urban development in Benin is the corruption-based management and the problem of meritocracy. As a matter of fact, local administration should innovate and opted for new policy meaning that it necessary to reinvent the local government management.

It is not any more a secret that in many municipalities of Benin the political interest guide the city management which spoils the performance of policies adopted although the effectiveness of decentralization since 1999. In this context, the bottom-up approach seems to be the appropriate way for policy implementation and it effectiveness. Pike et al. (2006) define bottom-up development policies as those strategies that fundamentally aim at unleashing indigenous economic potential by favoring local competitive advantage, and where the involvement of local actors in designing, implementing and managing development strategies is crucial. Bottom-up policies emphasis more in local characteristics and innovation as catalysts of the regional capacity to learn, absorb and create knowledge as well as to translate such an economic valuable knowledge into economic growth (Ascani et al., 2012). In fact, local institutions are those who know the challenges of towns or cities and which policy will be better off. Sustainable urban development in Benin is also an effective policy in plans for expansions and densification in order to meet the need for accommodation for the growing cities.

These expansion plan will improve the social live and enhance cities attractively. 


\section{Urban Financing Strategy and Taxes Collection in Benin Communes}

The source of a region or municipality income is very limited and restricted due to the lack of economic activities or sometime because of the poor economic policy. The urban development will not be possible in an environment of financial resources scarcity. In most developing countries, the poor management of local government is related to the lack of financial resources and a convenient taxes collection policy. Local government need fund in order to pursue the development of the locality. For example they need funds to build infrastructures like settlement, schools and provide public services. The local government lack of ability to mobilize funds and collect taxes although they have the legal right to do so. In Benin for instance since decentralization became effective in 1999, the central government transfer necessary power to the locals government to collect taxes and assumed their financial autonomy through Act No. 1998-007 of 15 January 1999 on the financial system in the Republic of Benin. But it is clear that those locals government are unable to provide a good financing strategies and taxes collection ability in order to finance capital projects for their city.

The financial management at a local government level in Republic of Benin is very lurid which impede the sustainable development of the localities. First, there are lack of resources and the disposal few one is badly allocated. It is the responsibility of the central government to provide public services such education, water, and electricity to its citizens and the fast and easy way to do it is by providing funds to the local governments. The central government of Republic of Benin through the Ministry of Decentralization, Local Governance, Administration and Territorial Development, design different projects to support the local government financially for a better local development. Doing so, the central state design a certain numbers of mechanism to support local government such as a Municipal Development Support Fund (FADeC) (The FADeC is a budgetary mechanism for the allocation of operating and investment grants to municipalities. The modalities of financing local government should be decide in the Council of Ministers as decide by the law. PONADEC, is a policy designed to facilitate the achievement of the development objectives set by the government by making the territory a lever of development), the document of National Policy of Decentralization and Deconcentration (PONADEC) (CONAFIL is a national body for consultation, proposals and impetus for reforms in local finance) and The National Finance Commission (CONAFIL). However, it is important to signal that local government have legal right to collect taxes in their areas of competence like on the proceeds from direct and indirect taxes, the proceeds of any local taxes provided for in the General Tax Code and the proceeds of patronage dividends including the share accruing to the commune. Besides the support of the central government, there are also some NonGovernment Organization (NGOs) who accompanied local government financially and materially.

\section{Conclusion and Remarks}

This paper discuss the growth of cities in Republic of Benin, issues and challenges of urbanization. The cities growth challenges is not just the concern of Republic of Benin it is a global phenomenon which require the attention of all. The paper notice that the exponential growth of world population brought a new nomenclature of urban disparities. In the Republic of Benin, the principle challenges face by the urbanization process are as following: lack of adequate houses and modern infrastructure, poor management of local institutions and the problem of inundation in the big city of Cotonou. We also observe that in the implementation of policies, the button-up approach is the more appropriate and accurate way for a sustainable urban development. Then to reach, this development, the policies at a regional level should be design for a long-term agenda and these policies should take in account the socio-economic and the environment aspect. The policies should also be directed toward the emergence and growth of core peripheries region which require a rigorous planning.

The Knowledge based hiring in the regional level should be prioritize instead of politic affiliation base and also enhance innovation in administration management. The adequate policies for a regional development and it sustainability are bind with the legal and institutional frameworks, governance problem recognition and objectives of regional policy. An effective and sustainable policy should be explicitly define with a specific aims in order to monitor the process of it implementation.

\section{Acknowledgement}

I would like to thank Prof. Dr. Fatma DOĞRUEL for her advice on research methodology. I am also grateful to the anonymous reviewers for their different comments on the earlier versions of the manuscript.

\section{Ethics}

This article is original and contains not any published material. The corresponding author confirms that all of the other authors have read and approved the manuscript and no ethical issues involved.

\section{References}

Alberti, M. and L. Susskind, 1996. Managing urban sustainability: An introduction to the special issue. Environmental Impact Assessment Rev., 16: 213-221. DOI: 10.1016/S0195-9255(96)00070-4 
Ascani, A., R. Crescenzi and S. Iammarino, 2012. Regional economic development: Review. Wp1/03 search working paper.

Brundtland, G., M. Khalid, S. Agnelli, S. Al-Athel and B. Chidzero et al., 1987. Our Common Future ('brundtland report $\backslash$ ')

Freire, M., 2006. Urban planning: Challenges in developing countries. International Congress on Human Development MADRID, pp: 1-44.

Freire, M.E., S. Lall and D. Leipziger, 2014. Africa's urbanization: Challenges and opportunities. The Growth Dialogue.

Grizans, J, 2009. Urban issues and solutions in the context of sustainable development: A review of the literature (No. 92). Working Paper, Department of Environmental and Business Economics, University of Southern Denmark.

Henderson, J.V. and A.J. Venables, 2009. The dynamics of city formation. Rev. Economic Dynamics, 12: 233-254. DOI: 10.1016/j.red.2008.06.003

Hove, M., E. Ngwerume and C. Muchemwa, 2013. The urban crisis in sub-Saharan Africa: A threat to human security and sustainable development. Stability: Int. J. Security Development.

Maddick, H., 1963. Democracy, decentralisation and development. Asia Publishing House.

Madu, C.N., C. Kuei and P. Lee, 2017. Urban sustainability management: A deep learning perspective. Sustainable Cities Society, 30: 1-17. DOI: $10.1016 /$ j.scs.2016.12.012

Martine, G., 2005. Population/development/environment trends in a globalized context: Challenges for the 21st century. Genus, 61: 247-277.

Mabogunje, A, 1985. Geography-the bridge between natural and social sciences. Hrvatski Geografski Glasnik, 47: 183-217.
Muller-Eie, D. and L. Bjorno, 2016. Urban Sustainability and individual behavior. Sustainable Development, Brebbia C.A. (Ed). WIT Press: Southampton, UK, pp: 29-40.

Pike, A., A. Rodríguez-Pose and J. Tomaney, 2006. Local and Regional Development. Ist Edn., Routledge, ISBN-10: 1134248547, pp: 328.

Rogers, A., 1978. Migration, urbanization, resources and development and discussions. Alternatives for Growth: The Engineering and Economics of Natural Resources Development. NBER, pp: 147-238.

Rondinelli, D.A., 1981. Government decentralization in comparative perspective: Theory and practice in developing countries. Int. Rev. Administrative Sci., 47: 133-145.

Rondinelli, D.A., R.J. Nellis and G.S. Cheema, 1983. Decentralization in Developing Countries: A Review of Recent Experience. 1st Edn., World Bank, ISBN-10: 0821302353, pp: 99.

Sarre, P. and P. Smith, 2013. One World for one Earth: Saving the Environment. 1st Edn., Routledge, ISBN-10: 1134042582, pp: 196.

Talmaciu, M., 2014. Study on the relationships between institutions, governance and leadership and regional development policy in Romania. Procedia Eco. Finance, 15: 1281-1288.

DOI: $10.1016 / \mathrm{S} 2212-5671(14) 00589-9$

UN, 2005. Population challenges and development goals. United Nations Publications.

UN-Habitat. 2017. https://unhabitat.org/governance/

UN-Habitat. 2010. State of the world's cities 2010/2011: Bridging the urban divide. EarthScan. 